\title{
Comparative effects of four legume species on plasma lipids and faecal steroid excretion in hypercholesterolaemic pigs
}

\author{
BY SUSAN M. KINGMAN, ANN F. WALKER*, A. G. LOW \\ AND I. E. SAMBROOK \\ Department of Food Science and Technology, University of Reading, PO Box 226, \\ Reading RG6 $2 A P$
}

AND R. W. OWEN

PHLS, CAMR, Division of Biotechnology, Sensor Development Group, Porton Down, Salisbury, Wilts SP4 0JG

AND T. J. COLE

Dunn Nutritional Laboratory, Downhams Lane, Milton Road, Cambridge CB4 $1 X J$

(Received 26 February 1991-Accepted 8 May 1992)

\begin{abstract}
The effect of four species of legume seeds on plasma cholesterol levels and faecal steroid excretion was studied in pigs. Thirty-six growing boars were randomly allocated in groups of six to six diets which they ate continuously for $42 \mathrm{~d}$. The diets fed were: 1, a semi-purified (SP; control group 1) diet; $2, \mathrm{SP}+10 \mathrm{~g}$ cholesterol/kg (control group 2); 3, 4, 5, 6, SP + cooked legumes $(70: 30, w / w ;$ respectively baked beans (Phaseolus vulgaris), peas (Pisum sativum), lentils (Lens culinaris Medik.), butter beans (Phaseolus lunatus) ) $+10 \mathrm{~g}$ cholesterol/kg. Fasting blood samples were taken on days $0,14,28$, and 42 for the determination of total plasma cholesterol, high-density-lipoprotein (HDL)-cholesterol and triacylglycerols. Between days 7 and 11 and days 28 and 32 complete $5 \mathrm{~d}$ faecal collections were made for the measurement of neutral, acidic and conjugated steroids. After $42 \mathrm{~d}$ total cholesterol and HDLcholesterol levels were raised significantly in all groups, but to different extents. In comparison with control group 2, diet-induced hypercholesterolaemia was significantly inhibited in the groups consuming baked beans, peas and butter beans, although HDL-cholesterol levels were maintained. Faecal steroid excretion by the legume groups was not significantly different from that of control group 2 . The results suggest that the mechanism for the hypocholesterolaemic effect does not involve increased hepatic bile acid synthesis and thereby increased cholesterol clearance via the intestinal route.
\end{abstract}

Legumes: Hypocholesterolaemic effect: Lipid metabolism: Pigs

The mature seeds of several legume species have been shown to reduce plasma cholesterol levels in experimental animals and man (for a review, see Shutler et al. 1987). The effect is particularly marked in hyperlipidaemic and cholesterol-fed subjects. Some of the studies in rats on this effect have demonstrated a commensurate increase in the excretion of bile acids in the faeces in response to whole legume seeds or fractions of these (Mathur et al. 1964; Soni et al. 1982; Mahadevappa \& Raina, 1983). This increased excretion of steroids has, therefore, been implicated as the mechanism involved, and this has been associated variously with the dietary fibre, saponin or lipid fractions of the seeds.

\footnotetext{
* For reprints.
} 
Few of the studies on the hypolipidaemic effect of leguminous diets in humans have included measurements of faecal steroid excretion. Mathur et al. (1968) observed that substitution of chick peas (Cicer arietinum L.; Bengal gram) into a high-butter-fat diet significantly increased $24 \mathrm{~h}$ excretion of bile acids but did not affect neutral sterol excretion. However, the diets were not completely standardized in this study for their carbohydrate, protein and fat contents. In contrast, in the carefully controlled study of Anderson et al. (1984) using Phaseolus vulgaris (haricot beans) the excretion of bile acids in the faeces of human hyperlipidaemic subjects was reduced by $30 \%$, despite a decrease in plasma cholesterol. Similar observations have been made in studies using isolated soya-bean protein (Fumagalli et al. 1982).

The rat is not an ideal model for human lipid metabolism, having a dissimilar plasma lipid profile and responding poorly to atherogenic diets. It is, thus, possible that the reported increase in bile acid excretion by rats in response to legumes does not occur in humans. Indeed, the assumption of similarity between the species may have delayed investigation into the hypolipidaemic mechanism occurring in man.

In contrast to the rat, the pig has a plasma lipid profile very similar to that of man and responds quickly to hyperlipidaemic diets (Miller \& U1lrey, 1987). The object of the present study was to investigate the effects of the mature seeds from four different legume species on plasma lipid levels and faecal steroid excretion in pigs made hypercholesterolaemic by diet. The legume seeds used were analysed so that any differences in composition of their components might be related to the physiological effects they elicited.

MATERIALS AND METHODS

Animals

Thirty-six growing Large White $\times$ Landrace boars of starting weight $25-34 \mathrm{~kg}$ were used. These were housed in single floor pens or metabolic crates and maintained at $20 \pm 3^{\circ}$.

\section{Diets}

The formulations of the diets used are given in Table 1. Each diet was designed to provide approximately $12 \%$ of energy as protein, $40 \%$ of energy as fat (P:S ratio 0.31$)$ and $48 \%$ of energy as carbohydrate, in imitation of a typical UK dietary profile (Department of Health and Social Security, 1984). Diets 2-6 were supplemented with $10 \mathrm{~g}$ crystalline cholesterol $/ \mathrm{kg}$ which was mixed thoroughly with the soya-bean oil before preparation of the diets. The diets were fed at a level of $30 \mathrm{~g} / \mathrm{kg}$ body weight per d (dry weight) in two equal meals, with tap water $(2.51 / \mathrm{kg})$.

Marrowfat peas (Pisum sativum L.), red lentils (Lens culinaris Medik.) and butter beans (Phaseolus lunatus L.) were obtained dry, soaked overnight in deionized water, boiled until soft, and stored at $-15^{\circ}$ until required. Baked beans (Phaseolus vulgaris L.) in tomato sauce were obtained in catering cans.

\section{Diet treatments and sampling}

The animals were randomly allocated to six groups of six. Each group received the same diet for a period of 6 weeks: the animals were weighed weekly for assessment of diet requirements. Groups 1 and 2 received semi-purified diets (diet 1 without and diet 2 with added cholesterol) and acted as controls. Groups 3-6 received cholesterol-supplemented semi-purified diets together with the following cooked legumes $(300 \mathrm{~g} / \mathrm{kg}$ dry matter $)$ : baked beans (diet 3), marrowfat peas (diet 4), red lentils (diet 5), butter beans (diet 6). 
Table 1. Formulations of the diets $(\mathrm{g} / \mathrm{kg}$ dry matter $)$

\begin{tabular}{|c|c|c|c|c|c|c|}
\hline Diet & 1 & 2 & 3 & 4 & 5 & 6 \\
\hline Maize starch & $477 \cdot 0$ & 477.9 & $352 \cdot 0$ & $336 \cdot 8$ & 347.5 & $335 \cdot 0$ \\
\hline Sucrose & $84 \cdot 0$ & $84 \cdot 0$ & $62 \cdot 0$ & $86 \cdot 7$ & 86.7 & $86 \cdot 7$ \\
\hline Tallow & $130 \cdot 0$ & $130 \cdot 0$ & $133 \cdot 0$ & 133.0 & $133 \cdot 0$ & $133 \cdot 0$ \\
\hline Soya-bean oil & $45 \cdot 0$ & $45 \cdot 0$ & $42 \cdot 8$ & $42 \cdot 8$ & $42 \cdot 8$ & $42 \cdot 8$ \\
\hline Casein & $157 \cdot 0$ & $157 \cdot 0$ & $76 \cdot 0$ & $66 \cdot 4$ & $55 \cdot 7$ & $68 \cdot 2$ \\
\hline Cellulose & $57 \cdot 0$ & $57 \cdot 0$ & - & - & - & - \\
\hline $\begin{array}{l}\text { Baked beans } \\
\text { (Phaseolus vulgaris) }\end{array}$ & - & - & $300 \cdot 0$ & 一 & - & $-\cdots-$ \\
\hline $\begin{array}{l}\text { Marrowfat peas } \\
\text { (Pisum sativum) }\end{array}$ & - & - & $-\cdots$ & $300 \cdot 0$ & - & - \\
\hline $\begin{array}{l}\text { Red lentils } \\
\text { (Lens culinaris Medik.) }\end{array}$ & - & - & - & 一 & $300 \cdot 0$ & $\ldots$ \\
\hline $\begin{array}{l}\text { Butter beans } \\
\text { (Phaseolus lunatus) }\end{array}$ & - & - & - & - & $\cdots$ & $300 \cdot 0$ \\
\hline Mineral mix & $10 \cdot 0$ & $10 \cdot 0$ & $07 \cdot 0$ & $07 \cdot 0$ & 07.0 & 07.0 \\
\hline Vitamin mix & $02 \cdot 0$ & $02 \cdot 0$ & 01.4 & $01 \cdot 4$ & 01.4 & $01 \cdot 4$ \\
\hline Sodium chloride & $05 \cdot 0$ & $05 \cdot 0$ & $03 \cdot 5$ & $03 \cdot 5$ & $03 \cdot 5$ & $03 \cdot 5$ \\
\hline Choline chloride & $01 \cdot 1$ & $01 \cdot 1$ & $00 \cdot 8$ & 008 & 00.8 & $00 \cdot 8$ \\
\hline Dicalcium phosphate & $31 \cdot 0$ & $31 \cdot 0$ & $2 \mathrm{~J} \cdot 7$ & $21 \cdot 7$ & $21 \cdot 7$ & $21 \cdot 7$ \\
\hline
\end{tabular}

Fasting blood samples were taken by venepuncture from the anterior vena cava on days $0,14,28$ and 42 of the study. Complete $5 \mathrm{~d}$ faecal collections were made between days 7 and 11 (period 1) and between days 28 and 32 (period 2).

\section{Analyses}

Plasma was separated from the whole blood samples by low-speed centrifugation immediately after collection and stored frozen before analysis. Plasma cholesterol, highdensity-lipoprotein (HDL)-cholesterol and triacylglycerols were measured using a fully automated clinical analyser (Encore Clinical Chemistry System; Baker Instruments) and enzymic kits, as described previously (Shutler et al. 1989). The very-low-density lipoprotein (VLDL) + low-density lipoprotein (LDL) combined fraction was determined by difference.

Inter- and intra-assay coefficients of variation $(\%)$ for the analyses were : for cholesterol 1.8 and 1.1 respectively, and for triacylglycerols 3.6 and 2.8 respectively.

A representative sample of each $5 \mathrm{~d}$ faecal collection was freeze-dried and milled to a fine powder. Samples were analysed for neutral sterols, free bile acids and glycine and taurine amidates plus sulphated steroids by gas-liquid chromatography using the method of Almé et al. (1977) as modified by Owen et al. (1984).

All legume seeds were analysed raw, and for this purpose a sample of haricot beans was obtained from the suppliers of the canned baked beans. Crude protein was determined by the Kjeldahl method no. 2 of Marshall \& Walker (1978), and crude fat, ash and moisture by the Association of Official Analytical Chemists (1980) methods. Total, soluble and insoluble non-starch polysaccharides (NSP) were measured using the method of Englyst \& Cummings (1988). Starch was calculated by difference. The seeds were also analysed for fatty acids by the International Union of Pure and Applied Chemistry: Commission on Oils, Fats and Derivatives (1979) method and for plant sterols (Owen et al. 1984). 


\section{Statistical methods}

Statistical analysis was carried out using the Genstat 5 computer package. The data were analysed by analysis of variance (ANOVA), with pigs as blocks and diet crossed with linear and quadratic contrasts of period as the treatments. Where significant differences between treatments were established, individual differences between diet groups were tested by $t$ test, with significance based on a probability of $P<0.01$.

Relationships between plasma lipids and faecal steroid excretion were analysed using Pearson's correlation coefficient, $r$.

\section{RESULTS}

\section{General}

All pigs remained in good health throughout the study and weight gains were satisfactory. Diet refusal was negligible and occurred only transiently on commencement of the experimental diets.

\section{Plasma lipids}

Fig. 1 depicts the changes in total plasma cholesterol that occurred during the $42 \mathrm{~d}$ experimental period.

Between-group differences in the rate of increase of total cholesterol were found to be significant overall using ANOVA $(F 6.16,15$ and $90 \mathrm{df}, P<0.001)$ and were mostly explained in terms of the linear trend $(F 16.52,5$ and $90 \mathrm{df}, P<0.001)$.

The semi-purified diet without added cholesterol (diet 1) induced a small but significant increase in plasma cholesterol from a basal mean of $2.5 \mathrm{mmol} / 1$ to $3.6 \mathrm{mmol} / 1(P<0.01)$ over the $42 \mathrm{~d}$. This was caused by increases in both the HDL and VLDL+ LDL fractions (Tables 2 and 3) which were evident after $14 \mathrm{~d}$ and did not increase further with time on the diet.

Supplementation of the semi-purified diet with $10 \mathrm{~g}$ crystalline cholesterol $/ \mathrm{kg}$ (diet 2) provoked a large rise in total plasma cholesterol which was evident after $14 \mathrm{~d}$ and increased with time on the diet (Fig. 1). After $42 \mathrm{~d}$ the mean plasma cholesterol for the group was five times greater than its basal level $(P<0.001)$ and more than three times greater than that for diet 1 at the same time-point $(P<0.001)$. Most of the increase was associated with the VLDL + LDL fraction (Table 3), although HDL-cholesterol levels were also raised compared with basal levels $(P<0 \cdot 01$, Table 2$)$ and the elevation was greater than that observed for diet 1 , suggesting that a proportion of the HDL increment was produced in response to the cholesterol supplement per se.

In general, substitution of legumes into the diet led to plasma cholesterol levels that were lower than those of control group 2 but higher than those of control group 1 (Fig. 1). Diet induced hypercholesterolaemia was significantly inhibited in all four legume groups compared with control group 2 (baked beans, peas and butter beans $P<0.001$, lentils $P<0.01$ ). Butter beans suppressed hypercholesterolaemia so effectively that the rate of increase of plasma cholesterol was not significantly different from that of control group 1 $(P>0 \cdot 3)$.

The differences in total cholesterol caused by the legumes in the diet were related principally to differences in the VLDL + LDL fraction. For all four groups the rate of increase in this fraction over time was significantly reduced compared with control group 2 (baked beans, peas and butter beans $P<0.001$, lentils $P<0.01$ ). In contrast, for the groups consuming baked beans, peas and lentils, HDL-cholesterol levels were not significantly different from those of control group 2 . This suggests that the legume diets had a specific effect on the metabolism of the lower density lipoprotein fractions.

HDL:total cholesterol values (not shown) reflected the changes in cholesterol 


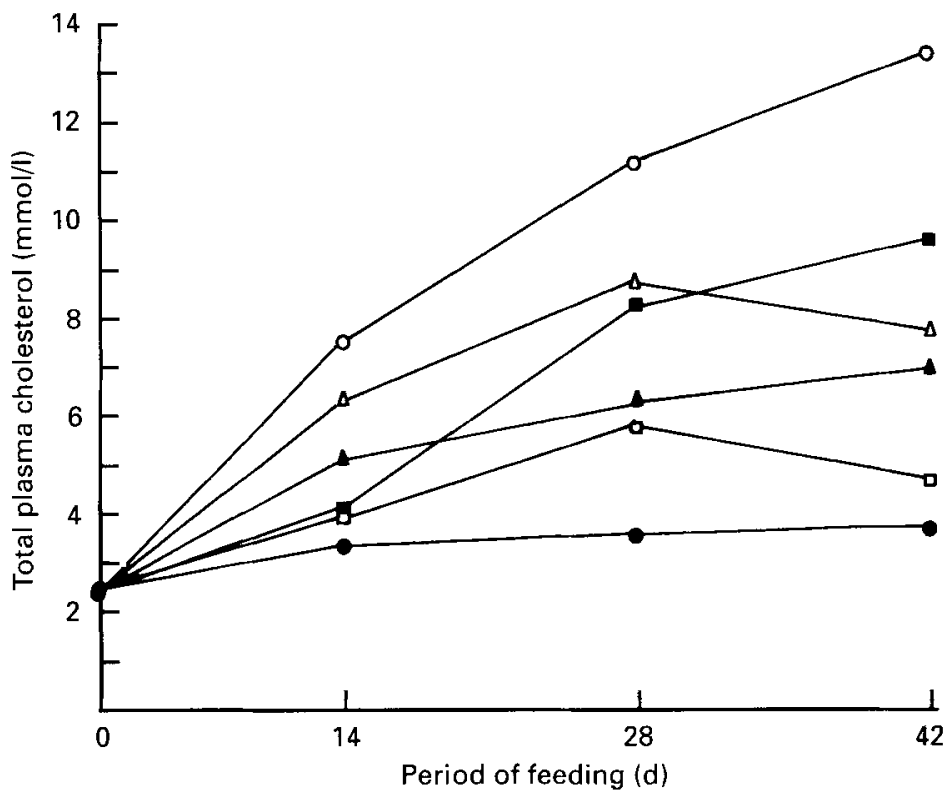

Fig. 1. Changes in mean plasma level of cholesterol of pigs consuming a hypercholesterolaemic semi-purified (SP) diet with or without substitution by one of four legume species. (O), Control diet 1 (SP); (O), control diet 2 $(\mathrm{SP}+10 \mathrm{~g}$ cholesterol $/ \mathrm{kg}) ;(\mathbf{\Delta})$, baked beans (Phaseolus vulgaris) (diet 3$) ;(\triangle)$, peas (Pisum sativum) (diet 4$) ;$ (ם), lentils (Lens culinaris Medik.) (diet 5); ( $\square$ ), butter beans (Phaseolus lunatus) (diet 6). Diets 3-6 contained $\mathrm{SP}+$ cooked legume $(70: 30, \mathrm{w} / \mathrm{w})+10 \mathrm{~g}$ cholesterol $/ \mathrm{kg}$. For details of diets and procedures, see Table 1 and pp. $410-411$.

Table 2. Mean values for high-density-lipoprotein (HDL)-cholesterol for four groups of pigs fed on different legume-containing diets and two control groups*

(Mean values and standard deviations)

\begin{tabular}{|c|c|c|c|c|c|c|c|c|c|c|}
\hline \multirow{3}{*}{$\begin{array}{l}\text { Period of feeding (d)... } \\
\text { Dietary group }\end{array}$} & \multicolumn{8}{|c|}{ HDL cholesterol $(\mathrm{mmol} / \mathrm{l})$} & \multirow{2}{*}{\multicolumn{2}{|c|}{$\begin{array}{c}\text { Statistical } \\
\text { significance of } \\
\text { difference: } P<\end{array}$}} \\
\hline & \multicolumn{2}{|c|}{0} & \multicolumn{2}{|c|}{14} & \multicolumn{2}{|c|}{28} & \multicolumn{2}{|c|}{42} & & \\
\hline & Mean & SD & Mean & $\mathrm{SD}$ & Mean & $\mathrm{SD}$ & Mean & SD & $v$. Diet 1 & $v$. Diet 2 \\
\hline 1 Control & 0.85 & 0.09 & 1.61 & 0.22 & 1.48 & 0.20 & 1.55 & 0.20 & & 0.01 \\
\hline 2 Control & 0.87 & $0 \cdot 18$ & $2 \cdot 29$ & 0.92 & 2.68 & $1 \cdot 10$ & 2.43 & 0.79 & 0.01 & \\
\hline $\begin{array}{l}3 \text { Baked beans } \\
\text { (Phaseolus vulgaris) }\end{array}$ & 0.87 & $0 \cdot 15$ & 1.97 & 0.77 & $2 \cdot 64$ & $1 \cdot 00$ & 2.68 & 0.77 & 0.01 & NS \\
\hline $\begin{array}{l}4 \text { Marrowfat peas } \\
\text { (Pisum sativum) }\end{array}$ & 0.86 & $0 \cdot 17$ & $2 \cdot 17$ & 1.01 & $2 \cdot 52$ & 0.84 & $2 \cdot 32$ & 0.55 & 0.01 & NS \\
\hline $\begin{array}{l}5 \text { Red lentils } \\
\text { (Lens culinaris Medik.) }\end{array}$ & 0.74 & 0.07 & 1.69 & 0.55 & 2.49 & 0.58 & $2 \cdot 38$ & 0.67 & NS & NS \\
\hline $\begin{array}{l}6 \text { Butter beans } \\
\text { (Phaseolus lunatus) }\end{array}$ & 0.82 & $0 \cdot 15$ & 1.54 & 0.39 & 1.89 & $0 \cdot 34$ & 1.85 & 0.28 & NS & NS \\
\hline
\end{tabular}

NS, not significant.

Variance ratio $F 2 \cdot 16, P=0.086$

* For details of diets and procedures, see Table 1 and pp. 410-4II. 
Table 3. Mean values for very-low-density lipoprotein $(V L D L)+$ low-density lipoprotein (LDL)-cholesterol for four groups of pigs fed on different legume-containing diets and two control groups*

(Mean values and standard deviations)

\begin{tabular}{|c|c|c|c|c|c|c|c|c|c|c|}
\hline \multirow{3}{*}{$\begin{array}{l}\text { Period of feeding }(d) \ldots \\
\text { Dietary group }\end{array}$} & \multicolumn{8}{|c|}{ VLDL- + LDL-cholesterol (mmol/1) } & \multirow{2}{*}{\multicolumn{2}{|c|}{$\begin{array}{c}\text { Statistical } \\
\text { significance of } \\
\text { difference: } P<\end{array}$}} \\
\hline & \multicolumn{2}{|c|}{0} & \multicolumn{2}{|c|}{14} & \multicolumn{2}{|c|}{28} & \multicolumn{2}{|c|}{42} & & \\
\hline & Mean & SD & Mean & SD & Mean & SD & Mean & SD & v. Diet 1 & $v$. Diet 2 \\
\hline 1 Control & 1.62 & $0 \cdot 37$ & 1.74 & 0.46 & $2 \cdot 04$ & $0 \cdot 19$ & $2 \cdot 03$ & $0 \cdot 12$ & & $0 \cdot 001$ \\
\hline 2 Control & $1 \cdot 52$ & $0 \cdot 25$ & $5 \cdot 16$ & $1 \cdot 21$ & $8 \cdot 44$ & 1.86 & 10.93 & $4 \cdot 35$ & $0 \cdot 001$ & \\
\hline $\begin{array}{l}3 \text { Baked beans } \\
\text { (Phaseolus vulgaris) }\end{array}$ & $1 \cdot 51$ & $0 \cdot 26$ & $3 \cdot 14$ & $1 \cdot 36$ & $3 \cdot 54$ & $1 \cdot 16$ & 4.09 & $1 \cdot 68$ & NS & 0.001 \\
\hline $\begin{array}{l}4 \text { Marrowfat peas } \\
\text { (Pisum sativum) }\end{array}$ & $1 \cdot 64$ & $0 \cdot 49$ & $4 \cdot 13$ & $2 \cdot 04$ & 603 & $4 \cdot 16$ & $5 \cdot 43$ & $2 \cdot 55$ & $0 \cdot 01$ & 0.001 \\
\hline $\begin{array}{l}5 \text { Red lentils } \\
\text { (Lens culinaris Medik.) }\end{array}$ & 1.67 & $0 \cdot 37$ & $2 \cdot 42$ & 0.52 & $5 \cdot 70$ & 1.87 & $7 \cdot 10$ & $2 \cdot 17$ & 0.001 & 0.01 \\
\hline $\begin{array}{l}6 \text { Butter beans } \\
\text { (Phaseolus lunatus) }\end{array}$ & 1.82 & $0 \cdot 70$ & $2 \cdot 41$ & 0.62 & $3 \cdot 76$ & 0.77 & $2 \cdot 83$ & 1.52 & NS & 0.001 \\
\hline
\end{tabular}

NS, not significant.

Variance ratio $F 11 \cdot 41, P<0.001$

* For details of diets and procedures, see Table 1 and pp. 410-411.

concentration in the lipoprotein fractions. While the mean values at $42 \mathrm{~d}$ for control groups 1 and 2 were 0.43 and 0.19 respectively, comparable values for legume-based diets were 0.4 , $0.33,0.26$ and 0.43 for baked beans, peas, lentils and butter beans respectively. ANOVA showed that only for lentils among the legume-based diets was the mean ratio significantly different $(P<0.01)$ from control group 1 , and this was the only diet for which the mean ratio was not significantly different from control group 2 .

Plasma triacylglycerol levels remained at basal level for all diets throughout the study.

\section{Faecal steroids}

Fig. 2 depicts the excretion of faecal neutral sterols, free bile acids and conjugated bile acids by each group during collection periods 1 and 2 . The excretion of steroids for diet 1 during the first collection period averaged $41 \mathrm{mg} / \mathrm{kg}$ per $\mathrm{d}$ of which approximately half was in the form of neutral sterols (cholesterol, coprostanol and plant sterols). The remainder consisted mainly of free bile acids, of which hyodeoxycholic acid was the predominant species, with a small contribution coming from steroid amidates and sulphates. Overall excretion of steroid during period 2 was not different from that of period 1 , although a greater percentage (76) of the total steroid occurred as neutral sterols.

In comparison with control group 1, control group 2 excreted significantly more neutral sterol (cholesterol and its bacterial conversion product coprostanol; $P<0.001$ ) during both collection periods. However, a difference in the excretion of bile acids by the two groups was not apparent until period 2, when a small but significant increase in the production of each bile acid species was observed (values not shown). Steroid amidates and sulphates were not affected by the cholesterol supplement.

Each of the pigs receiving legume-substituted diets 3-6 showed the same response to the cholesterol supplement as those receiving diet 2 , i.e. excretion of neutral sterols was significantly higher $(P<0.001)$ than that for the those receiving diet 1 during both collection periods, but an increase in the excretion of bile acids was not observed until 


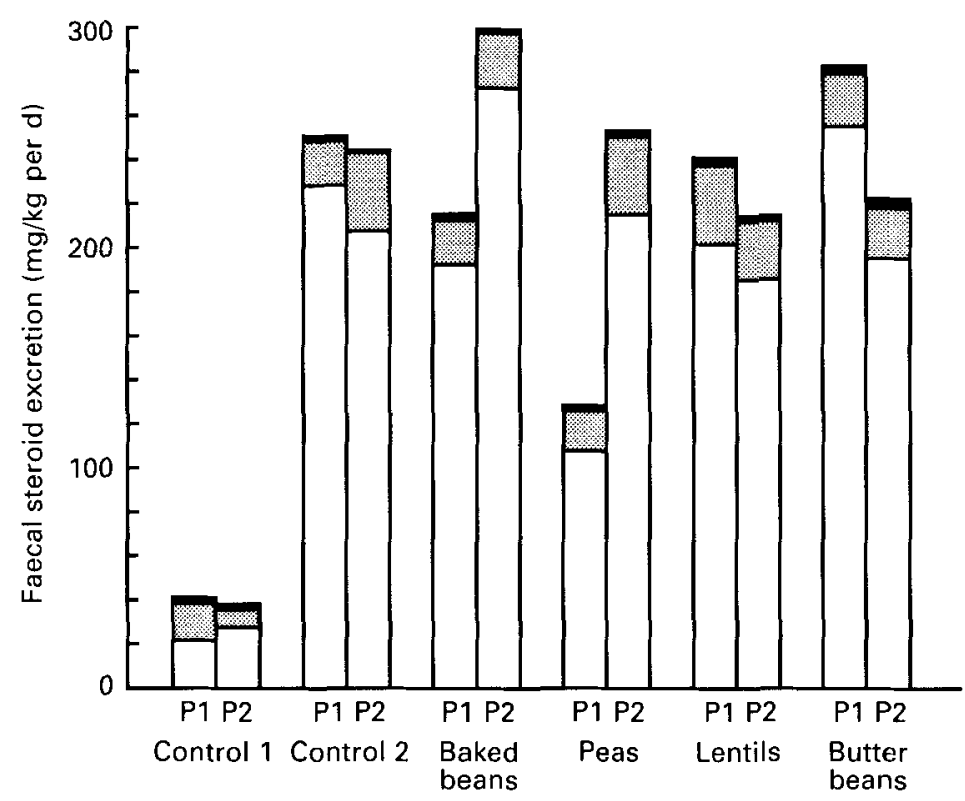

Fig. 2. Mean faecal steroid excretion of pigs consuming a hypercholesterolaemic semi-purified (SP) diet with or without substitution by one of four legume species during collection periods 1 (PI) and 2(P2). Control diet 1. SP: control diet 2, SP +10 g cholesterol $/ \mathrm{kg}$; diets containing legumes contained SP+cooked legume $(70: 30, \mathrm{w} / \mathrm{w}$; respectively baked beans (Phaseolus vulgaris), peas ( Pisum sanvum), lentils (Lens culinaris Medik.) or butter beans (Phaseolus lunatus)) $+10 \mathrm{~g}$ cholesterol $/ \mathrm{kg}$. ( $\square$ ), Total neutral sterols; (國), total bile acids; ( $\mathbf{\square}$ ), total steroid amidates and sulphates.

period 2. The amount of faecal steroid excreted by the pigs receiving baked beans, lentils and butter beans was not significantly different from that excreted by those given diet 2 during either period. Pigs receiving peas excreted significantly less neutral sterols than those receiving diet 2 during period $1(P<0 \cdot 01)$, but not during period 2 .

Minor changes in the excretion of individual steroids occurred as a consequence of substituting legumes into the diet. The only change common to pigs receiving the legumecontaining diets was an increase in the proportion of animal sterols occurring as coprostanol (a bacterial conversion product of cholesterol) compared with those given diet 2 (55v. 38\%,P<0.01 for all legume diets). This represented a return to values similar to those for diet 1 (values not shown).

Table 4 shows how much of the cholesterol provided in the diets of the five supplemented groups appeared in some form in the faeces. These values were obtained by calculating the amount of cholesterol fed to each animal on a particular day, and comparing this with the amount of steroid excreted in the faeces on the same day. The values assume no excretion of cholesterol resulting from endogenous synthesis. The percentage of dietary cholesterol excreted in the faeces varied widely within each group, but group means were similar, During period 1 the group consuming peas excreted less of their dietary cholesterol as steroid in the faeces than any other group, and this value was significantly different from control group $2(P<0.05)$. Other than this there were no significant differences in steroid excretion between the diet groups. 
Table 4. Excreted steroid in the faeces of pigs receiving a hypercholesterolaemic diet with or without substitution by one of four legume species $\dagger$

(Mean values and standard deviations; values are expressed as a percentage of dietary cholesterol)

\begin{tabular}{|c|c|c|c|c|}
\hline \multirow[b]{3}{*}{ Dietary group } & \multicolumn{4}{|c|}{ Steroid $(\%)$} \\
\hline & \multicolumn{2}{|c|}{ Period 1} & \multicolumn{2}{|c|}{ Period 2} \\
\hline & Mean & $\mathrm{SD}$ & Mean & SD \\
\hline 2 Control & 83 & 28 & 81 & 14 \\
\hline $\begin{array}{l}3 \text { Baked beans } \\
\text { (Phaseolus vulgaris) }\end{array}$ & 71 & 21 & 99 & 22 \\
\hline $\begin{array}{l}4 \text { Peas } \\
\quad(\text { Pisum sativum })\end{array}$ & $42^{*}$ & 18 & 84 & 52 \\
\hline $\begin{array}{l}5 \text { Lentils } \\
\text { (Lens culinaris Medik.) }\end{array}$ & 95 & 30 & 78 & 15 \\
\hline $\begin{array}{l}6 \text { Butter beans } \\
\text { (Phaseolus lunatus) }\end{array}$ & 93 & 76 & 73 & 26 \\
\hline
\end{tabular}

Mean value was significantly different from that for control diet $2: * P<0.05$

$\uparrow$ For details of diets and procedures, see Table 1 and pp. 410.411 .

Table 5. Composition of the four legume species used in the study (g/kg dry matter)

\begin{tabular}{|c|c|c|c|c|}
\hline & $\begin{array}{c}\text { Haricot } \\
\text { bean } \\
\text { (Phaseolus vulgaris) }\end{array}$ & $\begin{array}{c}\text { Marrowfat } \\
\text { ped } \\
\text { (Pisum sativum) }\end{array}$ & $\begin{array}{c}\text { Red } \\
\text { lentil } \\
\text { (Lens culinaris Medik.) }\end{array}$ & $\begin{array}{c}\text { Butter } \\
\text { bean } \\
\text { (Phaseolus lunatus) }\end{array}$ \\
\hline $\begin{array}{l}\text { Crude protein } \\
(\mathrm{N} \times 6.25)\end{array}$ & 241 & 233 & 292 & 227 \\
\hline Crude fat & 21 & 19 & 10 & 13 \\
\hline $\begin{array}{l}\text { Starch } \\
\text { (by difference) }\end{array}$ & 489 & 569 & 627 & 578 \\
\hline Ash & 39 & 26 & 19 & 32 \\
\hline Total NSP & 188 & 153 & 52 & 150 \\
\hline $\begin{array}{l}\text { Plant sterols } \\
(\mathrm{mg})\end{array}$ & 763 & 405 & 566 & 559 \\
\hline
\end{tabular}

NSP, non-starch polysaccharide.

Relationships between plasma lipid levels and the excretion of faecal steroids

In general, plasma lipid levels were found to be unrelated to the excretion of steroids in the faeces. As assessed by Pearson's correlation coefficient, there were no significant relationships between plasma cholesterol level and the excretion of total steroids, total neutral steroids or total bile acids when the group was taken as a whole ( $n$ 36). During period 1 the excretion of cholesterol itself was positively related to the plasma cholesterol level at $14 \mathrm{~d}(r 0.359, P<0.05)$. A similar relationship was observed when comparing cholesterol excretion during period 2 with the plasma cholesterol level at $42 \mathrm{~d}$, but this did not quite reach statistical significance.

Amongst the pigs receiving the cholesterol supplement ( $n$ 30) there was a negative relationship between the plasma cholesterol level at $14 \mathrm{~d}$ and the excretion of lithocholic acid during period $1(r-0.521, P<0.01)$. The relationship was not significant if the values for diet 1 were included in the analysis. Paradoxically, during period 2 there was a positive 


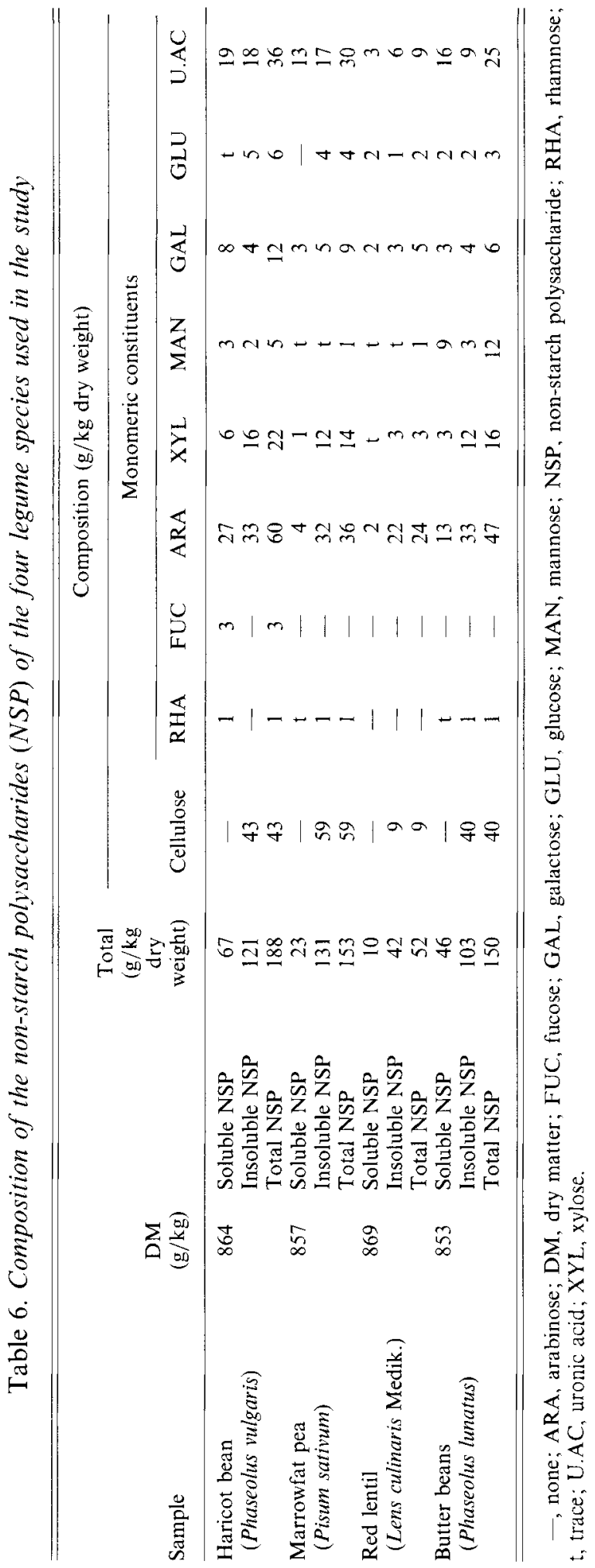


relationship between the excretion of lithocholic acid and the plasma cholesterol level at $42 \mathrm{~d}$ when data from all animals was included in the analysis $(r 0.409, P<0.05)$ but not when the analysis omitted diet 1 . No other significant relationships were observed between plasma lipid levels and the excretion of faecal steroids.

\section{Composition of the legumes}

The proximate composition of each legume species is given in Table 5. Haricot beans, marrowfat peas and butter beans contained very similar amounts of protein, fat, starch and ash; red lentils contained lower levels of non-starch polysaccharides (NSP) and ash but proportionately more protein and starch owing to the removal of their hulls.

Crude fat $(\mathrm{g} / \mathrm{kg})$ in the legume seeds ranged from 10 for red lentils to 21 for haricot beans. The main fatty acids detected were palmitic $\left(\mathrm{C}_{16: 0}\right)$, oleic $\left(\mathrm{C}_{18: 1}\right)$, linoleic $\left(\mathrm{C}_{18: 2}\right)$ and linolenic $\left(\mathrm{C}_{18: 3}\right)$ (values not shown). Haricot beans contained the highest level of polyunsaturates $(72 \mathrm{~g} / 100 \mathrm{~g}$ total fatty acids) and butter beans the highest level of saturates ( $29 \mathrm{~g} / 100 \mathrm{~g}$ total fatty acids). There were large differences in the fatty acid profiles of the four legumes; however, it is unlikely that these were important determinants of plasma cholesterol levels because of the very small quantities of legume oil consumed by the animals. Plant sterols were also present in very small amounts (Table 5).

With the exception of lentils the legumes contained high levels of NSP which were predominantly insoluble and comprised largely cellulose plus arabinose- and xylose-based polymers (Table 6). The highest level of soluble NSP $(67 \mathrm{~g} / \mathrm{kg})$ was found in haricot beans. Red lentils contained less than one-third of the NSP observed in the other legumes, but the composition of the NSP present was similar to that of the other species.

\section{DISCUSSION}

In the present study hypercholesterolaemia in pigs was induced by feeding a semi-purified diet supplemented with cholesterol. In response to this supplement the excretion of neutral sterols in the faeces was greatly increased. It is likely that this increase represented unabsorbed dietary sterol rather than an increase in hepatic synthesis; estimates of cholesterol absorption from the diet vary but it is thought that up to $80 \%$ of that presented to the gut mucosa is not absorbed by it (Grundy, 1983). In humans, excretion of cholesterol and coprostanol is increased on cholesterol feeding and most of the increase is due to unabsorbed dietary cholesterol (Quintao et al. 1971; Nestel \& Poyser, 1976).

A significant increase in bile acid excretion in response to the cholesterol supplement was not seen until period 2, and when it did occur it was not large, amounting to only twice the excretion seen with the semi-purified diet alone. In some animal species increased bile acid excretion does appear to be a major compensatory mechanism for increased cholesterol absorption (Hulcher \& Margolis, 1982). However, this has not been demonstrated conclusively in humans (Quintao et al. 1971; Nestel \& Poyser, 1976), and the present study suggests that it is not a major defence mechanism against cholesterol overload in pigs.

Diet-induced hypercholesterolaemia in pigs was reduced when legumes were included as part of the diet. The observed reduction in plasma cholesterol was associated with a decrease in its concentration in circulating LDL, but did not appear to be associated with increased excretion of steroid in the faeces. These findings are similar to those of Anderson et al. (1984) who showed that humans consuming a controlled diet containing haricot beans as a source of soluble NSP experienced a reduction in plasma cholesterol, most of which occurred in the LDL fraction and which was not associated with an increase in faecal steroid excretion. The mechanism proposed by this group to explain the effect was that of reduced hepatic cholesterol synthesis mediated by propionate. The basis of this hypothesis 
is that soluble NSP is fermented by the colonic flora with the production of propionic acid. This volatile fatty acid is readily absorbed and transported to the liver where it inhibits hydroxymethylglutaryl-CoA reductase (EC 1.1.1.88; HMG-CoA reductase), the ratelimiting enzyme of cholesterol synthesis. The reduced cholesterol synthesis is thought to be reflected in decreased plasma cholesterol levels.

In support of this hypothesis, the present study showed lentils, which contained the least total and soluble NSP, to be the least effective legumes with regard to cholesterol reduction. However, in spite of this it seems implausible that the propionate hypothesis can explain our results which were obtained under conditions of considerable cholesterol influx to the liver. Under these circumstances endogenous cholesterol synthesis would probably have been maximally inhibited by accumulation of endproduct, and it seems unlikely that further inhibition of hepatic synthesis by propionate would have had a measurable influence on plasma cholesterol levels. In future studies it may be helpful to measure the activity of $\mathrm{HMG}-\mathrm{CoA}$ reductase in the liver to assess the extent of hepatic cholesterol synthesis.

Nevertheless, it is clear from the results of the present study and that of Anderson et al. (1984) that the steroid-binding hypothesis is not sufficient to explain the hypocholesterolaemic action of legumes in all cases. Indeed, the selective reduction of the LDL fractions in these and other studies suggests that legumes may instead have a specific effect on the metabolism of VLDL, intermediate-density lipoproteins (IDL) or LDL particles. Plasma lipoprotein levels are a measure of the interplay between supply by the liver and demand for their lipid constituents by the tissues. A reduction in plasma LDL therefore indicates either an increase in their catabolism or a reduction in their synthesis.

In an experiment designed to monitor the effect of baked beans on the turnover of LDL in pigs we observed that the fractional catabolic rate of ${ }^{125}$ I-labelled LDL was the same in response to a hyperlipidaemic diet with or without baked beans, despite differences in the plasma cholesterol levels of the two groups (Shutler, 1988). Thus, baked beans appear to exert an effect on the synthesis of LDL by a mechanism not yet understood.

Selective lowering of LDL in the absence of increased faecal steroid excretion has also been observed in response to soya-bean protein (Kim et al. 1978; Noseda et al. 1980; Fumagalli et al. 1982), and this has led others to suggest that the effect is due to a reduced synthesis of LDL mediated by an altered balance of amino acids. The mechanism has not been clearly identified but two hypotheses are of interest. The limiting amino acid of soya bean and most other legumes is methionine, an essential amino acid which is required, among other things, for the formation of the methyl donor $S$-adenosyl methionine (SAM). SAM is functional in the synthesis of choline for phosphatidyl choline or lecithin, which is the principal phospholipid associated with LDL. This led Olson et al. (1958) to propose that the cholesterol-lowering effects of vegetable proteins could be the result of a relative deficiency of methionine or choline, or both, leading to limited numbers of LDL particles being available for the transport of cholesterol in the plasma.

This hypothesis would explain the observation of Terpstra et al. (1982) that the differential effects of animal and vegetable proteins only occur when the experimental animals or subjects are hypercholesterolaemic, since the quantities of methionine required would be directly related to the amount of cholesterol being processed by the liver. However, Kim et al. (1978) tested this hypothesis and found that supplementation of soyabean protein with free methionine up to the level found in casein did not alter its hypocholesterolaemic properties when fed to hyperlipidaemic pigs. Similar results were obtained by Hamilton \& Carroll (1976) in rabbits.

Legume proteins have a relatively low lysine: arginine value in comparison with animal proteins. This observation has received much attention from Kritchevsky et al. (1982) who 
have demonstrated that the atherogenicity of a protein may be directly proportional to its lysine:arginine value. These authors showed that supplementing soya-bean protein with lysine to bring it up to the lysine:arginine value of casein raised plasma cholesterol levels in rabbits above those seen with soya-bean protein alone. Several mechanisms for the effect have been suggested, including stimulation of lipid absorption from the intestine by lysine, stimulation of glucagon release by arginine, and inhibition of hepatic arginase $(E C$ 3.5.3.1) activity by lysine.

Analysis of the legumes used in the present study did not indicate any obvious component(s) which might have elicited the reduced plasma cholesterol levels seen.

The authors are grateful to Ministry of Agriculture, Fisheries and Food for a postgraduate award to S. M. K. They also wish to thank Heinz Ltd for the donation of baked beans. Thanks are also due to H. A. Smith for expert technical assistance.

\section{REFERENCES}

Almé, B. A., Bremmelgaard, A., Sjovall, J. \& Thomassen, P. (1977). Analysis of metabolic profiles of bile acids in urine using lipophilic anion exchange and computerised gas-liquid chromatography-mass spectrometry. Journal of Lipid Research 18, 339-362.

Anderson, J. W., Story, L., Sieling, B., Chen, W.-J. L., Petro, M. S. \& Story, J. (1984). Hypocholesterolaemic effects of oat-bran or bean intake for hypercholesterolaemic men. American Journal of Clinical Nutrition $\mathbf{4 0}$, $1146-1155$.

Association of Official Analytical Chemists (1980). Official Methods of Analysis, 13th ed. Washington, D.C.: Association of Official Analytical Chemists.

Department of Health and Social Security (1984). Diet and Cardiovascular Disease : Committee on Medical Aspects of Food Policy. Report on Health and Social Subjects no. 28. London: H.M. Stationery Office.

Englyst, H. N. \& Cummings, J. H. (1988). Improved method for measurement of dietary fiber and non-starch polysaccharides in plant foods. Journal of the Association of Official Analytical Chemists 71, 808-814.

Fumagalli, R., Soleri, L., Farina, R., Mantero, O., Noseda, G. \& Gatti, E. (1982). Faecal cholesterol excretion studies in type II hypercholesterolaemic patients treated with soyabean protein diet. Atherosclerosis 43, $341-353$.

Grundy, S. M. (1983). Absorption and metabolism of dietary cholesterol. Annual Review of Nutrition 3, 71-96.

Hamilton, R. M. G. \& Carroll, K. K. (1976). Plasma cholesterol levels in rabbits fed low fat low cholesterol diets; effects of dietary proteins, carbohydrates and fibre from different sources. Atherosclerosis 24, 47-62.

Hulcher, F. H. \& Margolis, R. D. (1982). Rate-limiting, diurnal activity of hepatic microsomal cholesterol-7hydroxylase in pigeons with high serum cholesterol. Biochimica et Biophysica Acta 712, 242-249.

International Union of Pure and Applied Chemistry: Commission on Oils, Fats and Derivatives (1979). Standard Methods for the Analysis of Oils, Fats and Derivatives, 6th ed. pp. 96-98 [C. Paquot, editor]. Oxford: Pergamon Press.

Kim, D. N., Lee, K. T., Reiner, J. M. \& Thomas, W. A. (1978). Effects of a soy protein product on serum and tissue cholesterol concentrations in swine fed high-fat, high-cholesterol diets. Experimental and Molecular Pathology 29, 385-399.

Kritchevsky, D., Tepper, S. A., Czarnecki, S. K. \& Klurfeld, D. M. (1982). Atherogenicity of animal and vegetable protein: influence of the lysine to arginine ratio. Atherosclerosis 41, 429-431.

Mahadevappa, V. G. \& Raina, P. L. (1983). Hypocholesterolaemic effect of cowpea in rats on atherogenic diet. Indian Journal of Medical Research 78, 819-823.

Marshall, C. M. \& Walker, A. F. (1978). Comparison of a short method for Kjeldahl digestion using a trace of selenium as a catalyst, with other methods. Journal of the Science of Food and Agriculture 29, 940-942.

Mathur, K. S., Khan, M. A. \& Sharma, R. D. (1968). Hypocholesterolaemic effect of Bengal gram. British Medical Journal i, 30-31.

Mathur, K. S., Singhal, S. S. \& Sharma, R. D. (1964). Effect of Bengal gram on experimentally induced high levels of cholesterol in tissues and serum in albino rats. Journal of Nutrition 84, 201-204.

Miller, E. R. \& Ullrey, D. E. (1987). The pig as a model for human nutrition. Annual Review of Nutrition 7 , 361-382.

Nestel, P. J. \& Poyser, A. (1976). Change in cholesterol synthesis and excretion when cholesterol intake is increased. Metabolism 25, 1591-1599.

Noseda, G., Fragiacomo, C., Descovich, G. C., Fumagalli, R., Bernini, F. \& Sirtori, C. R. (1980). Clinical studies on the mechanism of action of the soya bean protein diet. In Drugs Affecting Lipid Metabolism, pp. 355-362 [R. Fumagalli, D. Kritchevsky and R. Paoletti, editors]. Amsterdam: Elsevier/North Holland Biomedical Press. 
Olson, R. E., Vester, J. W., Gursey, D., Davis, N. \& Longman, D. (1958). The effect of low protein diets upon serum cholesterol in man. American Journal of Clinical Nutrition 6, 310-324.

Owen, R. W., Thompson, M. H. \& Hill, M. J. (1984). Analysis of metabolic profiles of steroids in the faeces of healthy subjects undergoing chenodeoxycholic acid treatment, by liquid-gel chromatography and gas-Jiquid chromatography-mass spectrometry. Journal of Steroid Biochemistry 21, 593-600.

Quintao, E. C. R., Grundy, S. M. \& Ahrens, E. H. Jr (1971). Effects of dietary cholesterol on the regulation of total body cholesterol in man. Journal of Lipid Research 12, 233-247.

Shutler, S. M. (1988). Investigations into the hypocholesterolaemic effect of legumes. PhD Thesis, University of Reading.

Shutler, S. M., Bircher, G. M., Tredger, J. A., Morgan, L. M., Walker, A. F. \& Low, A. G. (1989). The effect of daily baked bean (Phatseolus vulgaris) consumption on the plasma lipid levels of young, normo-cholesterolaemic men. British Journal of Nutrition 61, 257-265.

Shutler, S. M., Walker, A. F. \& Low, A. G. (1987). The cholesterol-lowering effect of legumes. I. Effects of the major nutrients. Human Nutrition: Food Sciences and Nutrition 41F, 71-86.

Soni, G. L., George, M. \& Singh, R. (1982). Role of common Indian pulses as hypocholesterolaemic agents. Indian Journal of Nutrition and Dietetics 19, 184-190.

Terpstra, A. H. M., van Tinteln, G. \& West, C. E. (1982). The hypocholesterolaemic effect of dietary soy protein in rats. Journal of Nutrition 112, 810-817. 